\title{
The Chilean Sectoral Innovation Systems: An Approach from The National Innovation Survey
}

\author{
Cristián Gutiérrez ${ }^{1 *}$, Verónica Roa P.2, Jerome Smith ${ }^{1}$
}

\begin{abstract}
This paper proposes a configuration and characterisation of the economic sectors in Chile applying Malerba's sectoral innovation systems approach. Its objective is to examine the existence of sectoral systems of innovation in Chile and their characteristics.

Using data from the Chilean Tenth Innovation Survey of Firms, a three-step statistical analysis was performed. In the first step, 15 variables were chosen and converted by factor analysis into four components reflecting the configuration of the sectoral system. In the second step, a cluster analysis was carried out to determine the characterisation of the sectors. In the final step, a simple econometric model was developed to estimate a proxy for the propensity to patent of the economic sectors.

It is possible to discover the existence of three groups of sectoral innovation systems. One is characterised by a low propensity to patent. Another one uses market information and some effort in R\&D to innovate. A third one is characterised by a strong use of market sources, high effort in $\mathrm{R} \& \mathrm{D}$, strong networking and collaboration, and a close interaction with the industrial property system.

This paper shows the usefulness of composite variables in identifying those sectors with higher propensity to patent. In particular, the factor networks and collaboration is the most important. This last is important to highlight in terms of policies in science and technology that aim to establish formal mechanisms to share common knowledge strengthening the relationships among the different players of the innovation process.
\end{abstract}

Keywords: sectoral innovation system; factor analysis; cluster analysis; national innovation survey; R\&D; economic sectors.

Submitted: January $31^{\text {st }}, 2021 /$ Approved: May $17^{\text {th }}, 2021$

\section{Introduction}

This paper proposes and discusses a configuration and characterisation of the economic sectors in Chile through Malerba's sectoral innovation systems approach using data from the Chilean Tenth Innovation Survey of Firms 2015 - 2016. It poses the following research question: how can economic sectors in Chile be categorised and characterised from an innovation perspective? Our argument is that the economic sectors in Chile can be grouped according to correlated variables that together present qualities from which it is possible to draw conclusions in terms of the similarities shared by the sectors that make up the different groups. A crucial task is to justify these variables and the components that they make up from a sectoral innovation perspective.

In the past decades, the system of innovation approach has become relevant to explain innovative capabilities at different levels such as nations, regions and sectors. The origins of the approach date back to the decades of the 1980s and 1990s with the work of Freeman (1987), Lundvall (1992) and Nelson (1993). The concept appears for the first time in 1987 by Freeman who defined an innovation system as "the network of institutions in the public and private sectors whose activities and interactions initiate, import, modify and diffuse new technologies" (Freeman, 1987 pp. 1 cited in Edquist, 1997). Then Nelson in 1993 presents his empirical work on innovation systems studying fifteen different countries. In this study, Nelson defines a national innovation system as " $a$ set of institutions whose interactions determine the innovative performance ... of national firms" and Lundvall (1992) defines an innovation system as "the elements and relationships which interact in the production, diffusion and use of new, and economically useful, knowledge ... and are either located within or rooted inside the borders of a nation state" (both cited in OCDE 1997, p. 11). These studies inspired the work of other authors at a less aggregated level such as regional innovation studies (e.g. Storper, 1995, Cooke et al., 1997, Asheim and Isaksen, 1997) and sectoral innovation studies (e.g. Breschi and Malerba, 1997, Malerba, 2002). Botta (2013) points out that a main difference among these levels of analysis is the boundaries that limit the system under study. In a national system of innovation, the boundaries are the frontiers of the nation or country. In a regional system of innovation, the boundaries are geographical. In a sectoral system of innovation, the boundaries are marked largely by the interaction of the actors that interplay to achieve innovation in a sector. Therefore, the national system is a high level of analysis and aggregation and there is a weakness in its limits to explain the performance of sectors within the same country. For this reason, a more appropriate approach to examine the determinants of innovation and performance of the economic sectors is Malerba's approach on sectoral innovation systems.

In terms of the advantages of the systems of innovation approach, Edquist (1997) highlights first of all that the approach places innovation and learning at the centre of the analysis and this helps to better understand the symbiosis between the application of new or combined knowledge and its transformation into economically significant products and processes. In an innovation system, learning can be observed in different activities performed by the various actors, for example innovative firms that launch new products to the market.

(1) Escuela de Administración y Economía, Univ. Católica Silva Henríquez, Santiago de Chile

(2) CINCEL-ANID, Ministerio de Ciencia, Tecnología, Conocimiento e Innovación, Santiago de Chile

*Corresponding author: cgutierrez@ucsh.cl

ISSN: 0718-2724. (http://jotmi.org)

Journal of Technology Management \& Innovation @ Universidad Alberto Hurtado, Facultad de Economía y Negocios. 
Secondly, the holistic and interdisciplinary view of the approach helps to consider a wide range of determinants of innovation and in different spheres such as the economic, institutional and political ones. In this paper this can be viewed through innovative intensity by the firms and the relation of innovative firms with the industrial property system. Thirdly, the approach considers a historical perspective, which helps to understand the development of the system over time. Although in this paper the data used does not allow us to directly observe the co-evolution among innovation, knowledge, institutions and organisations, it is acknowledged that innovation is a result of a process of knowledge accumulation. Fourthly, systems differ from one another in terms of their knowledge base, $\mathrm{R} \& \mathrm{D}$ expenditure, organisations and institutions. Moreover, the approach focuses on interdependency and non-linearity which means that due innovations are the result of new and combined knowledge generated and used by the different actors of the system. The relationship among actors is crucial; innovation does not occur in isolation. In this paper differences in the knowledge base of sectors and interdependency can be observed through the collaboration of innovative firms with other actors such as universities, laboratories, clients and suppliers. Finally, it is not possible to define an optimal system of innovation due to the fact that innovation systems are never in equilibrium and the learning processes are dynamic. In summary, as Malerba (2004) points out, in a sectoral innovation systems approach, the sectors are viewed as multidimensional, integrated and dynamic.

As for the limitations, Edquist (1997) indicates that a central element of an innovation system is that institutions do not mean the same for authors who study the subject. Some of them consider institutions as synonyms of organisations, whereas others use the term to indicate the rules of the game that shape the interaction of actors. In this paper we understand institutions as laws, regulations, habits and routines that shape the interactions among actors, both enhancing and hampering innovation. Along the same lines, there may be some conceptual ambiguities in using the approach due to a large diversity of definitions of innovation systems, and moreover, the limits of the system can also be blurred. In this paper we define a system of innovation from a sectoral perspective, that is, considering the limits of the economic sectors as given by the interactions of the innovate firms of each sector with other actors such as customers, suppliers, universities and public research institutions. Finally, Edquist (1997) stresses that system of innovation is more a conceptual framework rather than a formal theory. We agree with this, and for this reason what this paper presents should be viewed as a proposal of how it is possible to configure and characterise, and in this sense understand, the economic sectors in Chile from an innovation perspective.

Regarding the state of the art, there is no evidence of studies connected with economic sectors in Chile from a sectoral innovation systems approach using data from the national innovation survey. The closest research considering the Chilean context is the work of Calvo and Martínez (2017) who analysed the effects of innovative activities in firms in terms of their productivity at national and sectoral levels using data from the seventh, eighth and ninth national innovation survey. This is a quantitative study where the authors applied the
Crépon et al. (1998) empirical model to, in the first place, examine the relationship between innovation inputs, innovation outcome and innovation productivity in the twelve economic sectors defined by them. Secondly, they identify and analyse similarities and differences of innovative activities and innovation drivers of sectors as well as an examination of the role of the types of innovation and research and development in the productivity of firms. On the other hand, the closest research in a different context from Chile is the work of Peraza and Mendizábal (2016) on sectoral systems of innovation in Spain. This work presents a configuration and characterisation of the sectoral systems of innovation in Spain applying a framework based on the work of Malerba and Mani (2009) and using data from the Spanish national innovation survey. The results show the most intensive sectors in innovation, the sources of collaboration and information considered by the innovative firms and the heterogeneity in the innovation dynamics performed by the Spanish sectors.

The methodology this research proposes (i.e. the use of factorial analysis and cluster analysis) has been used in research on innovation studies regarding national and regional systems of innovation, but not for a sectoral context. At the regional level, we highlight the research of Buesa et al. (2006) on the Spanish regional innovation systems that established a typology of these systems using data set up for the Spanish R\&D system. In the first phase, the authors applied a factorial analysis technique to obtain the main factors that impact innovation capabilities. Secondly, using these factors in a cluster analysis, the authors establish a typology of the Spanish R\&D system. Finally, in order to measure the innovative capabilities of the Spanish regions, using patents the authors calculated a regression with the factors obtained from the factorial analysis.

In another work, Buesa et al. (2010) also used factorial analysis to determine the determinants of regional innovation in Europe and then performed a regression using patents as the dependent variable in order to propose a knowledge production function for the studied system.

The sections below start with sectoral innovation systems as a theoretical framework and research methodology, followed by an exploratory data analysis and configuration of the sectoral innovation systems in Chile. Finally, a characterisation of the sectoral systems of innovation and an econometric exercise are presented, as well as the discussion and conclusions.

\section{Sectoral Innovation Systems as a Theoretical Framework}

As mentioned above, the work of Franco Malerba, e.g. the seminal paper 'Sectoral systems of innovation and production' from 2002, inspired and laid the foundations for the studies of sectoral systems of innovation both from qualitative and quantitative perspectives. We then base our theoretical framework on Malerba's work and define the building blocks of a sectoral system that we can observe from the analysis as follows:

i) The knowledge base and learning processes that support the innovative activities in the sector which differ from sector to sector. 
ii) The links and interactions among actors. The diversity of actors and the interactions (market and non-market relations) among them vary from sector to sector. Special attention has been given to the firms that interact with other actors such as universities and government agencies to carry out innovative activities, as the innovation systems approach proposes. On rare occasions, firms perform their innovative activities in isolation and then their relations with other agents become relevant.

iii) Institutions which include laws, regulations, habits and routines that shape the interactions among actors, both enhancing and hampering innovation.

It can be observed that these three elements differ from sector to sector and an analysis of them allows us to better understand the dynamics and structure of each sector. Using this approach from a sectoral perspective, we can observe innovation in Chile analysing the data from the national innovation survey. In the following sections we apply this framework to categorise the sectors and analyse them in the light of the data from the national innovation survey.

\section{Research Methodology}

The data used in this research was that from the Chilean Tenth Innovation Survey of Firms 2015 - 2016 produced by the Chilean Ministry of the Economy. This Survey considers 38 sectors $^{1}$ including agricultural and services sectors ${ }^{1}$. Due to the original data in its raw form not lending itself to an easy analysis, we extracted, cleaned and transformed it from its original form to the final database. This was performed using the $\mathrm{R}$ statistical computing language version 3.5.2 (2018-12-20). The following table shows the building blocks of the theoretical framework and associated variables of the sectoral innovation systems from the innovation survey. The variables do not come "as is" in the data, but rather are calculated and aggregated per sector; therefore, for each variable we include its definition or mathematical formula. Where necessary, we have abbreviated the names of the variables in the formulae.

Table 1. Variables of Sectoral Innovation Systems

\begin{tabular}{|c|c|c|}
\hline Building Block & Variable & Definition / Formula \\
\hline \multirow[t]{4}{*}{ Agents } & Quantity of Firms & Quantity of Firms per Sector \\
\hline & Quantity of Innovative Firms & $\begin{array}{l}\text { Quantity of Firms that Engage in } \\
\text { Innovative Activities* }\end{array}$ \\
\hline & \multirow{2}{*}{ Pct Innovative Firms } & Quantity of Innovative Firms \\
\hline & & Quantity of Firms \\
\hline \multirow[t]{5}{*}{ Innovation Output } & \multirow{3}{*}{ Pct New Improved Products Services } & Quantity of Firms with \\
\hline & & New or Improved Products or Services \\
\hline & & Quantity of Firms \\
\hline & \multirow{2}{*}{ Pct New Improved Products Services IF } & $\begin{array}{l}\text { Quantity of Innovative Firms with } \\
\text { New or Improved Products or Services }\end{array}$ \\
\hline & & Quantity of Innovative Firms \\
\hline \multirow[t]{18}{*}{ Knowledge Base } & Total Expenditure on Innovation & $\sum$ Total Expenditure on Innovation \\
\hline & \multirow{2}{*}{ Innovative Intensity } & Total Expenditure on Innovation \\
\hline & & Total Sales \\
\hline & \multirow{2}{*}{ Pct Expenditure Innovation Dedicated RD } & Expenditure on Internal RぬD \\
\hline & & Total Expenditure on Innovation \\
\hline & \multirow{2}{*}{ Pct Expenditure Innovation Dedicated External RD } & Expenditure on Internal RひD \\
\hline & & Total Expenditure on Innovation \\
\hline & \multirow{2}{*}{ Pct Expenditure Innovation Dedicated Total RD } & Total Expenditure on R\&D \\
\hline & & Total Expenditure on Innovation \\
\hline & \multirow[t]{2}{*}{ Pct Intensity Use Internal Information } & $\begin{array}{l}\text { Quantity of Firms that Use } \\
\text { Internal Information }\end{array}$ \\
\hline & & Quantity of Firms \\
\hline & \multirow{2}{*}{ Pct Intensity Use Market Information } & $\begin{array}{l}\text { Quantity of Firms that Use } \\
\text { Market Information }\end{array}$ \\
\hline & & Quantity of Firms \\
\hline & \multirow{2}{*}{ Pct Intensity Use Institutional Information } & $\begin{array}{l}\text { Quantity of Firms that Use } \\
\text { Institutional Information }\end{array}$ \\
\hline & & Quantity of Firms \\
\hline & \multirow{3}{*}{ Pct Intensity Use Other Sources Information } & Quantity of Firms that Use \\
\hline & & Other Sources of Information \\
\hline & & Quantity of Firms \\
\hline
\end{tabular}

${ }^{1}$ The classification of sectors is the United Nations Industrial Standard Classification of All Economic Activities (ISIC). Under this taxonomy, division 04 is reserved for each country to use as a bespoke sector. At the date of publication, we had not obtained from the Economy Ministry the precise classification defined in Chile, and hence we have named it "Bespoke Sector for Chile". 


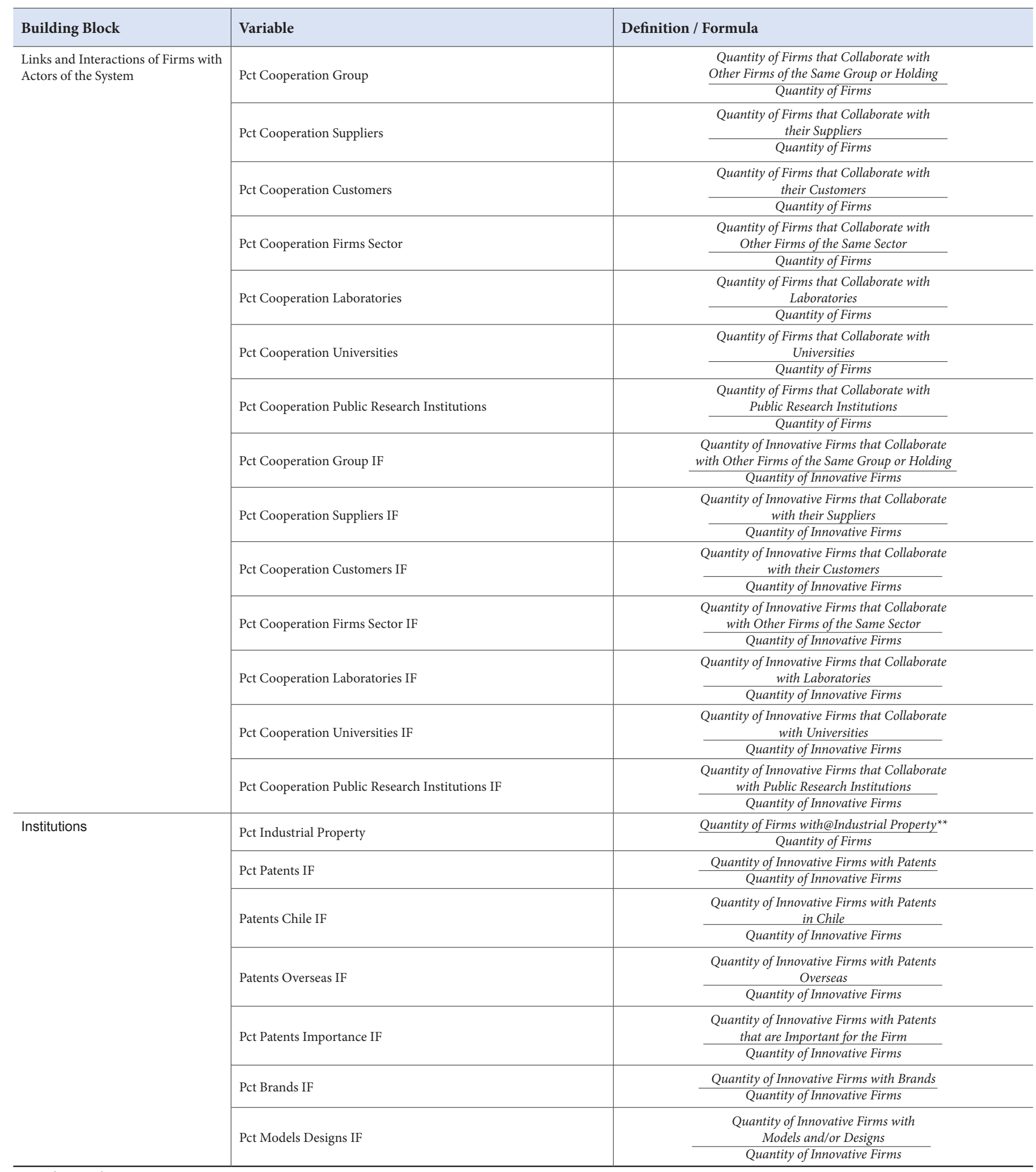

${ }^{*}$ : product and/or service

$* *$ : grouping patents, models and designs

Source: Own elaboration based on data and theoretical framework

ISSN: 0718-2724. (http://jotmi.org)

Journal of Technology Management \& Innovation @ Universidad Alberto Hurtado, Facultad de Economía y Negocios. 
The variables chosen are not only related to the effort in $R \& D$, the agents of the sectoral system or the results of the innovative effort. A matter of special interest is that relating to linkages that companies do when innovating. For example, the university-firm linkage triggers learning processes that have benefits for both the firm and the university, being one of the great strengths in leading countries in all types of innovation (Fagerberg et al., 2005).

Another important aspect in understanding the dynamics of innovation is detecting the sources of information that enable firms to innovate. The preponderance of internal and market sources of information over knowledge agents, coupled with the greater technological collaboration of suppliers compared to other agents, may help explain why many Chilean economic sectors engage in a type of innovation termed DUI (Doing, Using and Interacting) similar to that in Spain (see Peraza and Mendizábal, 2016). DUI tends to produce good results in small incremental innovations, but fails to produce major radical ones, redounding in lower economic returns to firms in the long run (Asheim, 2009).

Several statistical tests were performed, some of them to lend support to the relevance of using factor analysis techniques, namely: the correlation matrix between the variables that shows that there is a specific number of high correlations, the Kaiser-Meyer-Olkin (KMO) sample adequacy measure and the sphericity test of Barlett. The results of all of them supported the feasibility of factor analysis.

We used principal components as the factor analysis method to determine the factors of the sectoral innovation systems. In the selection of the factors and variables, the following criteria were used in conjunction:

a) The extracted factors are consistent and interpretable from the theoretical framework, which is one of the purposes of factor analysis.

b) Two criteria were used in determining the number of factors. The first one was the Kaiser or latent root criterion where a set of factors are extracted whose eigenvalues are greater than one. The second one was to keep a high percentage (greater than 75 percent) of the variance of the sample.

c) In the selection of variables, the value of their commonalities was used - many of them were close to unity - indicating the high degree of conservation of the variance of the variables which guarantees the reliability of the results. The interpretation of the factors thus obtained was made from the component matrix and the rotated component matrix using the Varimax ${ }^{2}$ method.
Therefore, the configuration of the sectoral innovation system was made through the factor analysis. After this, a cluster analysis was carried out to characterise the sectoral innovation system. To do so, the hierarchical clustering method of the "furthest neighbour" was used, which is based on joining objects using the so-called maximum distance.

\section{Results}

A measure of the innovative effort made by the different economic sectors is the innovative intensity, defined as the expenditure on innovation as a percentage of total revenue. Figure 1 shows that the four most innovation-intensive sectors are scientific research and development, fishing, legal and accounting activities, and crop and animal production.

In Figure 1, the relationship between innovative intensity and spending on $R \& D$ as a percentage of innovation expenditure can be observed. In general, sectors that are most intensive in innovation allocate a higher percentage of those resources to R\&D. Three of the most innovative sectors are among the eight that allocate more spending on R\&D. Only the fishing sector has a relatively low R\&D expenditure and high innovative intensity.

However, innovation systems - and each of their subsystems - are complex realities in which multiple agents participate and whose institutional configurations can be very varied. This means that, for the representation of these systems, it is essential to resort to the use of multiple variables (many of them highly correlated). In order to work on economic models with a large number of correlated variables or indicators, the information contained in the original variables must be summarised, creating a smaller number of abstract synthetic variables - which we will call factors, although they are identifiable with the elements that make up the sectoral innovation systems (Gutiérrez, 2018).

From the conceptual point of view, evolutionary theory underscores the heterogeneity of innovative behaviour as a multidimensional activity that is directly affected by its economic and social environment in which a large number of agents, institutions and factors participate that interact in a systemic framework based on a large number of interdependent relationships, which in turn make it difficult to establish unidirectional causal relationships. Furthermore, many aspects of the environment - not directly related to $\mathrm{R} \& \mathrm{D}$ - have a direct impact on innovative activities. All this implies that an innovation system is an abstract concept that is difficult to measure directly based on individual variables (Gutiérrez, 2018).

\footnotetext{
${ }^{2}$ With this type of rotation high saturation in some columns of the factorial matrix is achieved, - that is, a clear association between the variable and the factor - and in the remaining ones a saturation close to 0. For a more developed description of the Varimax rotation see Ferrán (2001), pp. 349-351 and Hair et al. (2001), p. 98.
} 
Figure 1. Sectors Ordered by \% Expenditure on R\&D and Innovative Intensity

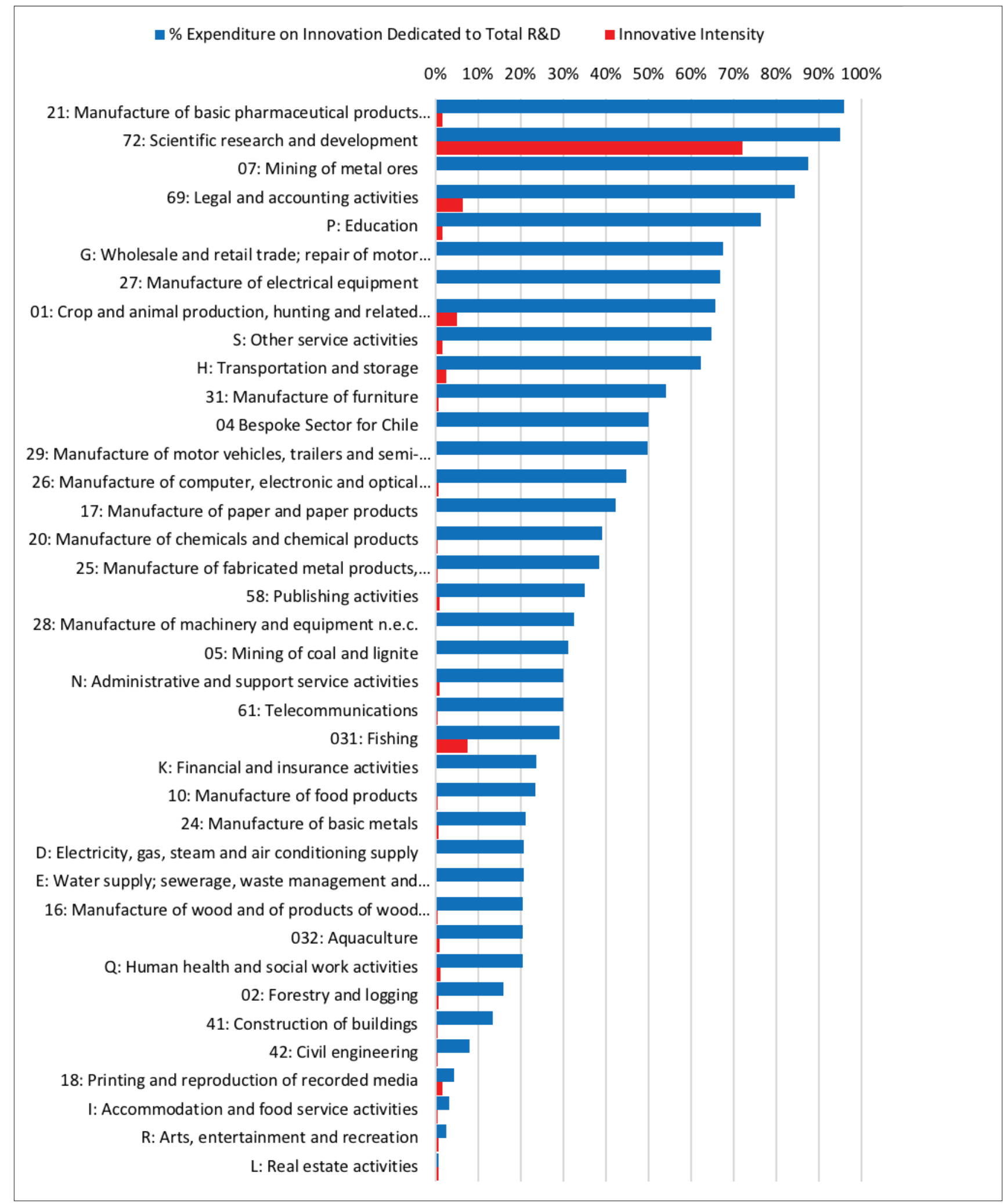

Source: Own elaboration based on data analysis 


\section{Configuration of Sectoral Innovation Systems in Chile}

From the final database, a factorial analysis known as principal components was carried out, with statistical information for the year 2017. The final solution considered fifteen variables (see table 2) obtaining four composite variables. The four-factor solution -as shown in the following table- retains 81.7 percent of the variance, so it can be said that it is correct to reduce the fifteen variables to four factors. All of the variables with suffix "IF" are defined for the subset of innovative firms only, which in turn are those which engage in innovation of products and (or) services.

Table 2. Factors

\begin{tabular}{|c|c|}
\hline $\begin{array}{l}\text { Innovative Intensity }(0,796) \\
\text { Intensity of Use of Institutional Information }(0,766) \\
\text { Cooperation with Group IF }(0,886) \\
\text { Cooperation with Suppliers IF }(0,741) \\
\text { Cooperation with Customers IF }(0,865) \\
\text { Cooperation with Firms of Sector IF }(0,806) \\
\text { Cooperation with Laboratories IF }(0,947) \\
\text { Cooperation with Universities IF }(0,921) \\
\text { Cooperation with Public Research Institutions IF }(0,954)\end{array}$ & $\begin{array}{l}\text { Industrial Property }(0,816) \\
\text { Patents IF }(0,724) \\
\text { Models Designs IF }(0,835)\end{array}$ \\
\hline Factor 3: R\&D Effort & Factor 4: Market Orientation \\
\hline
\end{tabular}

Source: Own elaboration based on data analysis

Although initially one might think that some variables show a very similar meaning, they are considered to have the necessary nuance that identifies different highlights of the sectoral innovation systems. Given that there is a significant heterogeneity of sectors, it can be affirmed that there will be cases in which said differences will be significant. Also, it should be noted that in this case, the number of variables - fifteen - is not high.

Considering that it is not intended to carry out a predictive, but a descriptive analysis, it is understood that it will be enriched using a greater number of indicators.

The assignment of a name to each factor has been based on their composition, clearly showing their correspondence with the essential elements of the innovation systems that have been reviewed in the theoretical framework.

To conclude the application of principal components factor analysis, it is worth clarifying that the scores of the four factors have been calculated for the year 2017 in the 38 economic sectors. These factor scores constitute composite measures of each factor for each sector, where the relationship of all the variables with the factor is considered, and not only with the highest saturation variables. These four new variables that are included in the final database summarise the original information, explaining 81.7 percent of the total variability of the sample and each of them being represented in a proportion equal to the commonality on the set of the four factors. The method selected to estimate the coefficients is linear regression, ${ }^{3}$ and its standardized - values is used later for the generation of clusters and econometric modelling.

It is important to underline that, since in the calculation of the factorial scores the relation of all the variables with each factor is taken into account, implicitly the interrelationships between the different elements that constitute the innovation systems are reflected.

\section{Characterisation of Sectoral Innovation Systems in Chile}

Once the configuration of the sectoral innovation systems was ascertained, a characterisation of parameters was made. From the factor variables, the cluster analysis was performed, which resulted in eight clusters composed of the different economic sectors. Clusters 1 and 4 include 9 sectors each; clusters 2 and 3 have 5 sectors each, while cluster 5 has 7. The cluster analysis leaves 3 independent sectors which, due to their specificities were treated as separate clusters (clusters 6, 7 and 8).

The ANOVA test was carried out to corroborate the conformation of the eight groups, rejecting the null hypothesis of equality of means among the 8 groups at $95 \%$ confidence for each of the four factors, as shown in the following table.

${ }^{7}$ With this method the resulting scores have mean 0 and variance equal to the square of the multiple rotation between the estimated factor scores and the true factor values. There is a normalisation of the data that becomes a mean of 0 and a standard deviation of 1 . 
Table 3. ANOVA Test

\begin{tabular}{l|r|r|r|r}
\hline & $\begin{array}{l}\text { Network and } \\
\text { Collaboration }\end{array}$ & $\begin{array}{l}\text { Interaction } \\
\text { with the IP } \\
\text { System }\end{array}$ & R\&D Effort & $\begin{array}{l}\text { Market } \\
\text { Orientation }\end{array}$ \\
\hline F & 23.931 & 15,684 & 13,040 & 13,084 \\
\hline D.F. & 7 & 7 & 7 & 7 \\
\hline $\begin{array}{l}\text { Signifi- } \\
\text { cance }\end{array}$ &, 000 &, 000 &, 000 &, 000 \\
\hline
\end{tabular}

Source: Own elaboration based on data analysis

According to the results obtained, we have the following typology of sectoral innovation systems.

Figure 2. Typology of the Sectoral Innovation Systems in Chile

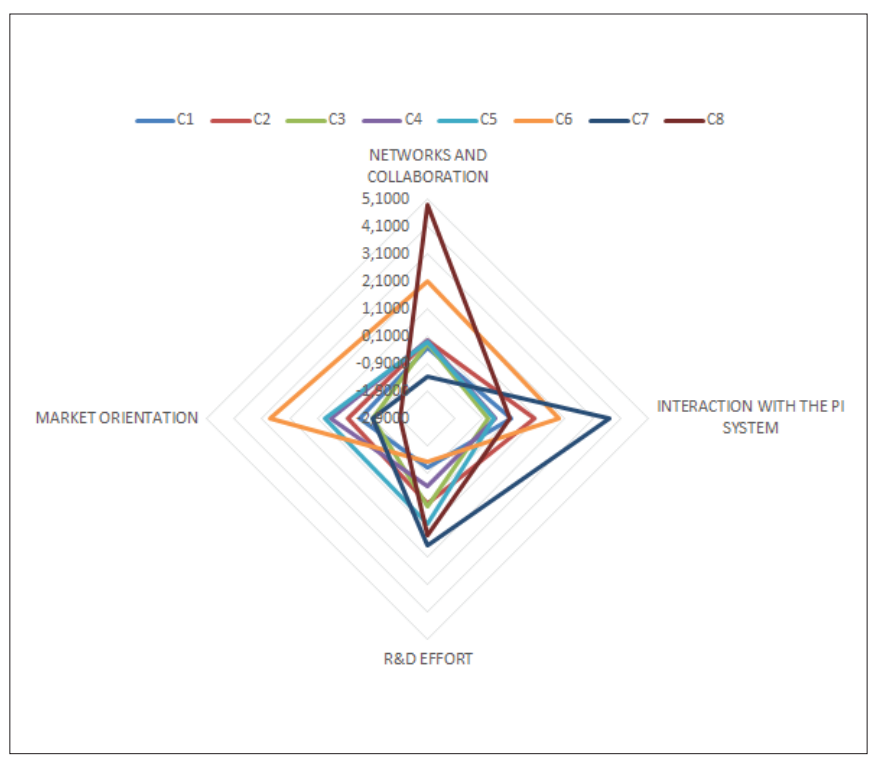

Source: Own elaboration based on data analysis

Then, from the analysis we can observe three types of sectoral systems of innovation for Chile: underdeveloped sectoral systems, developing sectoral systems, and developed sectoral systems, each of them described below.

\section{Type 1: Underdeveloped Sectoral Systems}

In this group are the sectors belonging to clusters 1, 2 and 3. They are systems that do not stand out in any particular factor, except for cluster 2 , which is prominent in the interaction with the industrial property system component, since it is composed of manufacturing sectors of relative complexity. The following table presents the sectors belonging to each of these clusters.
Table 4. Underdeveloped Sectoral Systems

\begin{tabular}{|c|c|}
\hline Cluster 1 (9 sectors) & Cluster 2 ( 5 sectors) \\
\hline $\begin{array}{l}\text { Fishing; printing and reproduction } \\
\text { of recorded media; construction of } \\
\text { buildings; civil engineering; publis- } \\
\text { hing activities; water supply, sewera- } \\
\text { ge, waste management and remedia- } \\
\text { tion activities; accommodation and } \\
\text { food service activities; real estate } \\
\text { activities; arts, entertainment, and } \\
\text { recreation. }\end{array}$ & $\begin{array}{l}\text { Manufacture of paper and paper } \\
\text { products; manufacture of chemicals } \\
\text { and chemical products; manufactu- } \\
\text { re of fabricated metal products, ex- } \\
\text { cept machinery and equipment; ma- } \\
\text { nufacture of electrical equipment; } \\
\text { education. }\end{array}$ \\
\hline
\end{tabular}

Crop and animal production, hunting and related service activities; forestry and logging; mining of coal and lignite; Manufacture of motor vehicles, trailers and semi-trailers; wholesale and retail trade, repair of motor vehicles and motorcycles; transportation and storage; other service activities.

Source: Own elaboration based on data analysis

It can be observed that cluster 1 is mainly made up of sectors related to services with a low propensity to patent and which dedicate very little effort to R\&D. On the other hand, cluster 3 is made up of sectors related to the extraction of natural resources with very low use of information from the market and with a low propensity to innovate.

\section{Type 2: Developing Sectoral Systems}

This group corresponds to the sectors belonging to clusters 4 and 5 . They are systems that stand out in some particular factor. While cluster 4 stands out in the market orientation factor, cluster 5 is prominent in the R\&D effort component. The following table presents the sectors belonging to each of these clusters.

Table 5. Developing Sectoral Systems

\begin{tabular}{l|l}
\hline Cluster $\mathbf{4}$ (5 sectors) & Cluster $\mathbf{5}$ (9 sectors) \\
\hline $\begin{array}{l}\text { Aquaculture; manufacture of wood } \\
\text { and of products of wood and cork, } \\
\text { except furniture; financial and in- } \\
\text { surance activities; administrative } \\
\text { and support service activities; hu- } \\
\text { man health and social work acti- } \\
\text { vities. }\end{array}$ & $\begin{array}{l}\text { dicinal chemical and botanical pro- } \\
\text { manufacture of computer, electronic } \\
\text { and optical products; manufacture } \\
\text { of machinery and equipment n.e.c; } \\
\text { manufacture of furniture; telecom- } \\
\text { munications; legal and accounting } \\
\text { activities; electricity, gas, steam and } \\
\text { air conditioning supply. }\end{array}$ \\
\hline
\end{tabular}

Source: Own elaboration based on data analysis

\section{Type 3: Developed Sectoral Systems}

In this group are the sectors 04 , metallic mining and scientific research and development. They are sectors that are conspicuous particularly in some of the elements of the configuration of innovation systems, but in general stand out far above the rest of the economic sectors, establishing clusters by themselves. Sector 04 is strong in using market 
sources, the scientific research and development sector is prominent in networking and collaboration, while the metal mining sector has a significant interaction with the industrial property system.

\section{Propensity to Patent by Sector}

It has been seen how the composite measures to construct the factors of the configuration of sectoral systems has been useful. We used the 'synthetic' variables previously calculated to estimate a proxy for the propensity to patent of the economic sectors using cross-sectional data. We propose an additive model, being common in this type of study (see Jaffe, 1989; Acs et al., 1992; Feldman, 1994; Anselin et al., 1997; Furman et al., 2002), according to the following specification:

\section{$K_{i}=\beta_{0}+\beta_{1} N_{E T W O R K S}+\beta_{2} R \& D_{-} E F F O R T_{i}+$ \\ $\beta_{3}$ MARKET_ORIENTATION ${ }_{i}+\beta_{4} I N T E R A C T I O N_{-} P I \_S Y S T E M_{i}+\varepsilon_{i}$}

The output variable refers to the new economically valuable sectoral knowledge in technological and relative terms $\left(\mathrm{K}_{\mathrm{i}}=\%\right.$ of companies that patent by economic sector), while the explanatory variables are the four factors of effort and environment calculated again from a new factor analysis extracting the patent variables: networks, $R \& D$ effort, market orientation, and interaction with the industrial property system.

An important issue involves the time lag between the R\&D effort and the time of the patent application. Empirical studies seem to show that this relationship is almost contemporary, at least regarding patents (Hall et al., 1986; Schmoch, 1999; OECD, 2004). In this way we have used the cross-sectional data to make the estimation.

In terms of the econometric results, it is important to point out that the results presented here aim to detect the relative weight of the determinants of innovation and knowledge at the sector level by means of an explanation function rather than obtaining an estimate of future output, as would be done by a prediction function. This has important methodological consequences. In addition to not requiring a structure of delays or lags between inputs and outputs, a prediction makes it less advisable to combine the regression techniques with other statistical techniques such as factor analysis, since the (non-standardised) regression coefficients thus obtained would not make reference to the elasticity of a specific variable, but instead would reflect the elasticity of the factor score, which depends on the change experienced by all the other variables included in the factor. Furthermore, by working with such heterogeneous sectoral realities, it causes errors to be greater and the variance to not be uniformly distributed along the regression plane, both of which are fundamental assumptions when estimating regressions for predictive purposes. The foregoing does not prevent the model from being optimised to the maximum by applying the relevant tests.

The results are presented in the following table and show that the factor that most impacts the percentage of companies that patent by sector is the one that accounts for networks and collaboration in the innovation system, followed by the effort in R\&D applied (plus the use of internal information). In third place is the interaction with the industrial prpoerty system which is approximated by the percentage of companies in the sector that register utility models and designs.

Table 6. Estimation Results. Output: \% of Companies that Patent by Economic Sector

\begin{tabular}{|l|l|}
\hline FACTOR & OLS \\
\hline NETWORKS & $\begin{array}{l}6.01 \\
(0.000)\end{array}$ \\
\hline R\&D EFFORT & $\begin{array}{l}4.73 \\
(0.000)\end{array}$ \\
\hline MARKET ORIENTATION & 1.40 \\
& $(0.231)$ \\
\hline INTERACTION WITH INDUSTRIAL PROPERTY & 4.33 \\
SYSTEM & $(0.001)$ \\
\hline Constant & 8.84 \\
& $(0.000)$ \\
\hline F test & 14.88 \\
& $(0.000)$ \\
\hline $\mathrm{R}^{2}$ & 0.643 \\
\hline $\mathrm{R}^{2}$ adjusted & 0.600 \\
\hline $\mathrm{N}^{\circ}$ Observations & 38 \\
\hline
\end{tabular}

In parentheses are the $\mathrm{p}$ values, in italics the non-significant coefficients at $99 \%$ confidence.

Source: Own elaboration based on data analysis

\section{Discussion and Conclusions}

According to our results the main conclusions of this paper are:

- It is possible to configure the Chilean sectoral innovation systems using composite variables in agreement with Malerba's theoretical approach. The reduction of 15 initial variables from the data of the Chilean National Innovation Survey, in 4 factors, using factor analysis, allows us to define the sectoral systems of innovation in Chile in terms of four building blocks: networks and collaboration, R\&D effort, interactions with the industrial property system and market orientation.

- Using these 4 factors (or building blocks) and its punctuations, it is possible to identify 8 clusters of sectoral systems, and group them in 3 categories: underdeveloped, developing and developed sectors. The first group includes $55.2 \%$ of the total Chilean sectoral innovation systems. On the other hand, the group of developed sectors includes only 3 sectors, reflecting the poor reality of Chile in terms of innovation and in agreement with data that reflects the lower effort in R\&D of the Chilean private sector (see Meller, 2015).

- Finally, a simple econometric model shows that the sectoral propensity to patent depends critically on the networks and collaboration in innovation of each sector. This has important implications for scientific and technological public policy to establish formal and official mechanisms to share common knowledge and 
best practices strengthening the relationships among the different actors of the innovation process. In addition, this also means extending the knowledge base at the sectoral level with focus on the triple helix perspective (Leydesdorff and Etzkowitz, 1998) and the firm's absorptive capacity (Cohen and Levinthal, 1990).

Future research should deepen the use of composite variables to explain sectoral innovation systems, including more data from innovation surveys to characterise the sectors in terms of their innovative efficiency and productivity, searching relationships among different levels of aggregation: sectoral, regional and national.

\section{References}

Acs, Z., Audretsch, D. \& Feldman, M. (1992). Real Effect of Academic Research: Comment. American Economic Review, 82-1, 363-367.

Anselin, L., Varga, A. \& Acs, Z. (1997). Local Geographic Spillovers between University Research and High Technology Innovations. Journal of Urban Economics, 42, 422-448.

Asheim, B. \& Isaksen, A. (1997). Location, agglomeration and innovation: towards regional innovation systems in Norway? European Planning Studies, 5, 299-330.

Asheim, B.T. (2009). Next Generation Regional Innovation Policy: How to Combine Science and User Driven Approaches in Regional Innovation Systems. Ekonomiaz, 70-1, 86-105.

Botta, E. (2013). Green growth: a case study on the danish and chinese sectoral innovation systems. IEFE - The Center for Research on Energy and Environmental Economics and Policy at Bocconi University, Working Paper n53.

Breschi, S. \& Malerba, F. (1997). Sectoral innovation systems: technological regimes, schumpeterian dynamics and spatial boundaries. In: Edquist, C. (ed.), Systems of innovation: technologies, institutions and organizations (pp. 130-56). London: Pinter.

Buesa, M., Heijs, J. \& Baumert, T. (2010). The determinants of regional innovation in Europe: A combined factorial and regression knowledge production function approach. Research Policy, 39, 722-735.

Buesa, M., Heijs, J., Martínez, M. \& Baumert, T. (2006). Regional systems of innovation and the knowledge production function: the Spanish case. Technovation, 26, 463-472.

Calvo, C. \& Martínez, C. (2017). Innovación I+D y productividad: Análisis sectorial para Chile. División de Innovación. Ministerio de Economía, Fomento y Turismo de Chile.

Cohen, W. M. \& Levinthal, D. A. (1990). Absorptive capacity: A new perspective on learning and innovation. Administrative Science Quarterly, 128-152.

Cooke, P., Gómez, M. \& Etxebarría, G. (1997). Regional innovation systems: institutional and organizational dimensions. Research Policy, 26(4-5), 475-491.
Crépon, B., Duguet, E., \& Mairesse, J. (1998). Research, innovation and productivity: an econometric analysis at the firm level. Economics of Innovation and new Technology, 7(2), 115-158.

Edquist, 1C. (1997). Systems of innovation: technologies, institutions and organizations. London: Pinter.

Fagerberg, J.; Mowery, D. \& Nelson, R. (2005). The Oxford Handbook of Innovation. Oxford, United Kingdom: Oxford University Press. Feldman, M. (1994). The Geography of Innovation. Dordrecht.

Ferrán, M. (2001). SPSS para Windows: Análisis estadístico. Madrid: Editorial McGraw-Hill.

Freeman, C. (1987). Technology policy and economic performance: lessons from Japan. London: Pinter.

Furman, J.L., Porter, M.E. \& Stern, S. (2002). The Determinants of National Innovative Capacity. Research Policy, 31, 899-933.

Gutiérrez, C. (2018). Eficiencia de los sistemas regionales de innovación en Europa y análisis econométrico de sus determinantes. Tesis para optar al grado de Doctor. Universidad Complutense de Madrid, España.

Hair, J.F., Anderson, R., Tatham, R. \& Black, A. (1999) Análisis multivariante de datos. Madrid.

Hall, B., Griliches, Z. \& Hausman, J. (1986). Patents and R and D: Is There a Lag? International Economic Review, 27-2, 265-283.

Jaffe, A. (1989). Real Effects of Academic Research. American Economic Review, 79-5, 957-970.

Leydesdorff, L. \& Etzkowitz, H. (1998). Triple Helix of innovation: introduction. Science and Public Policy, 25-6, 358-364.

Lundvall, B.Å. (1992). National systems of innovation: towards a theory of innovation and interactive learning. London:Pinter.

Malerba, F. (2002). Sectoral systems of innovation and production. Research Policy, 31(2), 247-264.

Malerba, F. (2004). Sectoral systems of innovation, concepts, issues and analyses of six major sectors in Europe. Cambridge University Press: Cambridge.

Malerba, F. \& Mani, S. (2009). Sectoral systems of innovation and production in developing countries. Cheltenham: Edward Elgar.

Meller, P. (2015). El déficit de innovación en Chile: ¿Qué hacer? Presentación en el festival de ciencia y cultura Puerto de Ideas Antofagasta en abril de 2015. Programa Cieplan-U.Talca.

Nelson, R. (1993). National systems of innovation: a comparative stu$d y$. Oxford: Oxford University Press.

OCDE (1997). National innovation systems. Organisation for Economic Cooperation and Development. 
OECD (2004). Compendium of Patent Statistics. Paris.

Peraza, E. \& Mendizábal, G. (2016). Sistemas sectoriales de innovación en España. Una tipología a partir de la encuesta sobre innovación en las empresas. Economía Industrial, 402, 117-127.
Schmoch, U. (1999). Eignen sich Patente als Innovationsindikatoren? En Boch, R. (ed.), Patentschutz und Innovation in Geschichte und Gegenwart. Frankfurt am Main et al.

Storper, M. (1995). The resurgence of regional economies, ten years later the region as a nexus of untraded interdependencies. European Urban and Regional Studies, 2, 191-221. 